\title{
Association of maternal hemoglobin and birth weight at Paropakar Maternity and Women's Hospital, Kathmandu
}

\author{
Ansari SR 1 , Baral G ${ }^{2}$ \\ ${ }^{1}$ Data manager, NESOG MNH project, ${ }^{2}$ Obstetrician \& Gynecologist, Paropakar Maternity and Women's Hospital.
}

Received: 10-Dec-2016; Accepted: 17-Dec-2016

Aims: To examine the association between maternal hemoglobin with birth weight.

Methods: Cross sectional study of obstetrics database at Paropakar Maternity and Women's Hospital. Hospital delivery of over 18 years of age women tested for Pearson correlation using SPSS-17.

Results: Total of 2085 cases analyzed. There was mean hemoglobin value of $12.05 \pm 1.30(95 \% \mathrm{CI}=11.992-12.103) \mathrm{g} / \mathrm{dL}$ and no any significant impact on mode of delivery $(\mathrm{p}=0.15)$ and neonatal death $(\mathrm{p}=0.736)$. There was a small but a significant correlation $(\mathrm{p}<0.01)$ of maternal age with hemoglobin $(\mathrm{r}=0.106)$ and birth weight $(\mathrm{r}=0.093)$; but a very small negative correlation between maternal hemoglobin and birth weight.

Conclusions: Optimal maternal hemoglobin during labor rules out any strong correlation with birth weight.

Keywords: birth weight; correlation; delivery; hemoglobin.

\section{INTRODUCTION}

Anemia had been a major cause of maternal morbidity and even of mortality around the globe especially across Africa, Asia and Latin America. ${ }^{1}$ Severe anemia would increase the risk of premature delivery, low birth weight and lower values of Agpar. ${ }^{2}$ The prevalence of anemia was found widespread in pregnant women and preschool children of India and highest in the world in 2009. ${ }^{3}$ Though the first two major causes of maternal mortality in Nepal is contributed by postpartum hemorrhage and hypertensive disease in pregnancy, there has been widespread prevalence of anemia in maternal population especially in rural Nepal. ${ }^{4}$ The iron deficiency is not the sole contributor of anemia. Studies have shown that anemia occurred also due to hookworm infestation, Plasmodium vivax malaria parasitemia and low serum retinol. However iron deficiency is the major contributor of anemia. Health status is improving by nutritional intervention; and malnutrition, anemia and several maternal factors prevalent previously are not the sole factors nowadays. ${ }^{5,6}$

Iron and folic acid supplementation in antenatal and postnatal period can improve pregnancy outcome in

\section{CORRESPONDENCE}

Mr Safiur Rahman Ansari

Data manager, NESOG MNH project, Paropakar Maternity and

Women's Hospital, Thapathali, Kathmandu

Email: isafiur@gmail.com

+977-9841748150 current as well as subsequent pregnancy, and reduce neonatal mortality and low birth weight as well..$^{7-13}$

However the risk of anemia has been decreasing with widespread prescribing of iron/folate during antenatal visits and better maternal nutrition. In the past about $42 \%$ of pregnant women had anemia worldwide of which $90 \%$ were in Africa or Asia. With vigorous iron/folate supplementation to pregnant women hemoglobin levels increased by $1.17 \mathrm{~g} / \mathrm{dL}$ in developed countries and $1.13 \mathrm{~g} / \mathrm{dL}$ in developing countries. ${ }^{14}$ A systematic review shows daily iron supplementation resulted in $69 \%$ reduction in incidence of maternal anemia. ${ }^{15}$ In contrast, iron supplementation to pregnant women with normal hemoglobin levels $(\mathrm{Hb} \geq 13.2 \mathrm{~g} / \mathrm{dl})$ failed to improve pregnancy outcomes and significantly increased hypertension. ${ }^{16}$ Thus, in the current context when maternal hemoglobin is normal or near normal the association between maternal hemoglobin and birth weight has become unclear.

The aim of this study was to examine the association between maternal hemoglobin with birth weight.

\section{METHODS}

This cross-sectional study was conducted using clinical database at Paropakar Maternity and Women's Hospital among hospital deliveries during 6 months from 15 May to 14 November 2016. The inclusion criteria set over 18 years of age and availability of 
data on delivery record and hemoglobin level at the time of admission. The variables were noted down and analyzed using SPSS-17. The distribution of both hemoglobin level and birth weight was checked for normality and Pearson correlation was calculated. $p$-value $<0.05$ was considered to have sufficient evidence for statistical significance.

\section{RESULTS}

Out of 2085 analyzable data on delivery record, 2066 (99.08\%) were live births, 19 (9.36 per 1000) were stillbirths (14 macerated and 5 fresh) and 57 (2.73\%) preterm deliveries. One-fourth of term deliveries had Cesarean sections. Sex ratio of newborn was 100:87. [Table-1]

Table-1: Mode of delivery at term $(\mathrm{n}=\mathbf{2 0 2 8})$

\begin{tabular}{|ll|}
\hline Normal Delivery & $1487(73.32 \%)$ \\
\hline LSCS & $493(24.30 \%)$ \\
Vacuum Delivery & $42(2.07 \%)$ \\
Breech Delivery & $6(0.30 \%)$ \\
\hline
\end{tabular}

The value of hemoglobin ranges from $6.3 \mathrm{~g} / \mathrm{dl}$ to $16.5 \mathrm{~g} / \mathrm{dl}$ with mean value of $12.05 \pm 1.30(95 \%$ $\mathrm{CI}=11.992-12.103)$. The distribution of hemoglobin value is presented in box plot. [Figure-1]

Figure-1: Distribution of hemoglobin level at admission

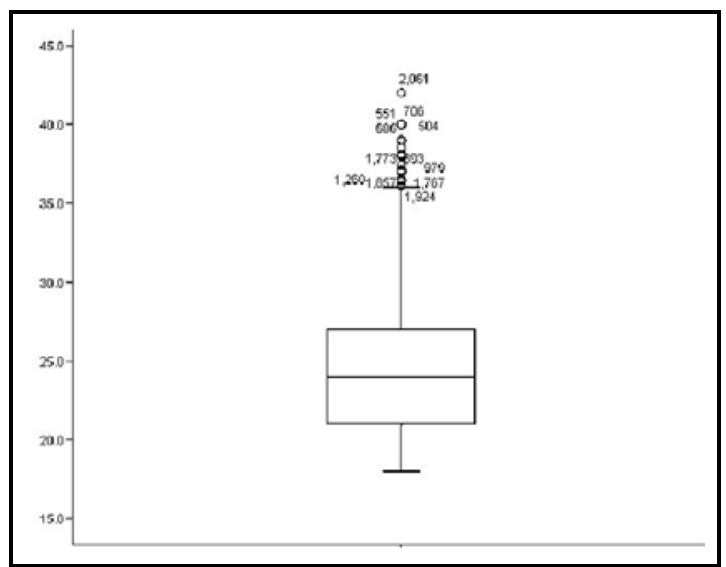

The maternal hemoglobin has no significant impact on mode of delivery $(p=0.15)$ neither the neonatal death $(p=0.736)$. [Table-2 and 3]
Table-2: Distribution of mean hemoglobin level by mode of delivery

\begin{tabular}{|lll|}
\hline $\begin{array}{l}\text { Mode of } \\
\text { delivery }\end{array}$ & Frequency & $\begin{array}{l}\text { Hemoglobin Mean } \pm \text { SD } \\
(\mathbf{9 5 \%} \text { CI) }\end{array}$ \\
\hline $\begin{array}{l}\text { Normal } \\
\text { Delivery }\end{array}$ & 1487 & $12.02 \pm 1.302(11.95-12.08)$ \\
$\begin{array}{l}\text { Premature } \\
\text { Delivery }\end{array}$ & 57 & $11.96 \pm 1.447(11.57-12.34)$ \\
\hline $\begin{array}{l}\text { LSCS } \\
\text { Vacuum } \\
\text { Delivery }\end{array}$ & 493 & $12.17 \pm 1.262(12.06-12.28)$ \\
$\begin{array}{l}\text { Breech } \\
\text { Delivery }\end{array}$ & 6 & $11.92 \pm 1.262(11.53-12.32)$ \\
\hline
\end{tabular}

Table-3: Distribution of mean hemoglobin level by neonatal outcome

\begin{tabular}{|lll|}
\hline $\begin{array}{l}\text { Hemoglobin } \\
\text { level }\end{array}$ & Frequency & $\begin{array}{l}\text { Hemoglobin Mean } \pm \text { SD } \\
(\mathbf{9 5 \%} \text { CI) }\end{array}$ \\
\hline $\begin{array}{l}\text { Live Baby } \\
\text { Macerated } \\
\text { stillbirth }\end{array}$ & 2066 & $12.05 \pm 1.300(11.99-12.10)$ \\
\hline $\begin{array}{l}\text { Fresh } \\
\text { stillbirth }\end{array}$ & 5 & $12.13 \pm 1.173(11.45-12.81)$ \\
\hline
\end{tabular}

Birth weight ranges from 550 grams to 4900 grams with mean value of $2973.10 \pm 485.60$ grams $(95 \%$ $\mathrm{CI}=2952.24$ to 2993.95 grams).[Figure-2]

Figure-2: Distribution of birth weight

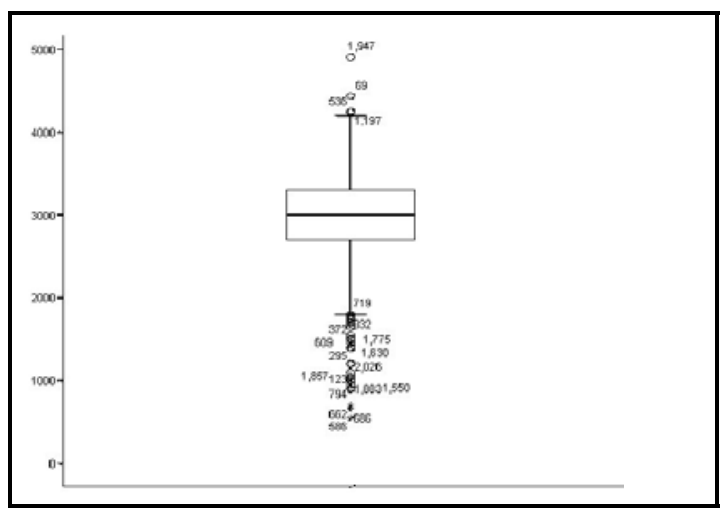

Median maternal age is 24 years and eldest one was 42 years old. Lower and higher maternal age demonstrate significant impact $(\mathrm{p}<0.01)$ on the mode of delivery from normal delivery towards Cesarean Section respectively; and maternal age doesn't have significant impact on neonatal death $(p=0.219)$. [Table-4 and Figure-3] 
Table-4: Distribution of Mean age by mode of delivery

\begin{tabular}{|c|c|c|}
\hline $\begin{array}{l}\text { Mode of } \\
\text { delivery }\end{array}$ & Frequency & Age Mean \pm SD $(95 \% \mathrm{CI})$ \\
\hline $\begin{array}{l}\text { Normal } \\
\text { Delivery }\end{array}$ & 1487 & $24.13 \pm 4.15(23.916-24.338)$ \\
\hline LSCS & 493 & $25.83 \pm 4.39(25.438-26.215)$ \\
\hline $\begin{array}{l}\text { Premature } \\
\text { Delivery }\end{array}$ & 57 & $24.17 \pm 4.58(22.954-25.386)$ \\
\hline $\begin{array}{l}\text { Vacuum } \\
\text { Delivery }\end{array}$ & 42 & $24.35 \pm 3.83(23.155-25.545)$ \\
\hline $\begin{array}{l}\text { Breech } \\
\text { Delivery }\end{array}$ & 6 & $23.08 \pm 2.87(20.071-26.096)$ \\
\hline
\end{tabular}

Figure-3: Relation of maternal age and neonatal death

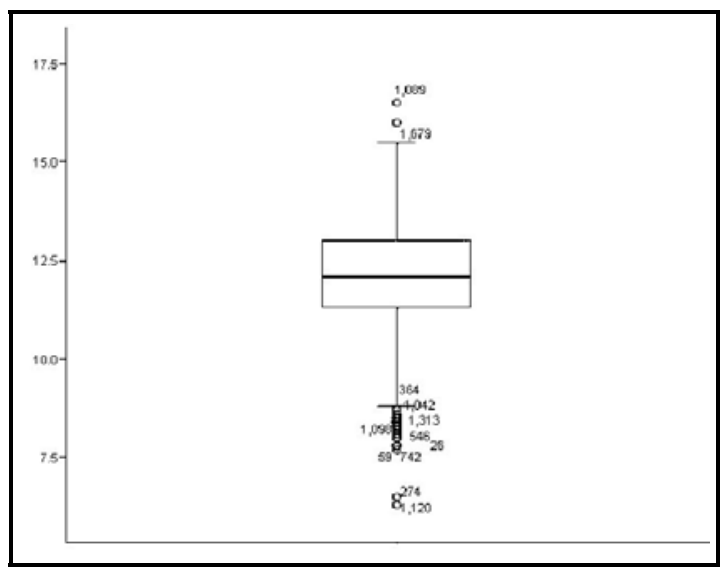

There was a small but a significant correlation $(p<0.01)$ between maternal age and hemoglobin (Pearson coefficient, $r=0.106$ ) as well as in between age and birth weight (Pearson coefficient, $r=0.093$ ). There was a very small negative correlation between maternal hemoglobin level at admission and birth weight in any delivery $(\mathrm{p}=0.035, \mathrm{r}=-0.046)$, live birth $(\mathrm{p}=0.033, \mathrm{r}=-0.047)$ and full term delivery $(\mathrm{p}=0.014, \mathrm{r}=-0.054)$.

\section{DISCUSSION}

This study shows the incidence of stillbirths at 9.36 per 1000 which is lower than expected 32 per 1000 prevalent in South Asia and sub-Saharan Africa but higher than 4.2 per 1000 documented in England. ${ }^{17,18}$ A decade old study carried out in 2000 in Nepal had recorded 27 stillbirths per 1000 total births and 23 per 1000 in 2009. ${ }^{19}$ The condition has improved but our result might not give accurate prevalence of stillbirths in community because all the deliveries we recorded are carried out in a tertiary level hospital and we involved mother of age over 18 years.

The low prevalence of premature delivery in our study (i.e. $2.73 \%$ ) is because we enrolled mother of age $18 \mathrm{yrs}$ and above and mean hemoglobin level was optimal (i.e. $12.05 \mathrm{mg} / \mathrm{dl}$ ). The studies have shown that both low $(<7 \mathrm{~g} / \mathrm{dl})$ and high $(>14.5 \mathrm{~g} / \mathrm{dl})$ maternal hemoglobin levels have been related to poor fetal outcome. Studies have shown that high incidence of premature deliveries is related to young maternal age $(<18$ years) and lower hematocrit/hemoglobin level. ${ }^{2,20,21}$

A study covering nine Asian countries in 2010 shows Cesarean Section rate of $27.3 \%$ among all deliveries which is slightly higher than this study $(24.3 \%) .{ }^{22}$

The mean birth weight was found to be 2973.10 grams ( $95 \% \mathrm{CI}=2952.24$ to 2993.95 grams) which is similar or slightly greater to older study carried in Nepal using iron supplementations in 2005. ${ }^{10}$

\section{CONCLUSIONS}

There is ample evidence to link maternal anemia to low birth weight. However this association between maternal hemoglobin level and birth weight diminishes as maternal hemoglobin reaches to optimal level. Our study provides evidence to rule out any strong correlation between maternal hemoglobin level and birth weight when maternal hemoglobin lies in normal ranges.

\section{REFERENCES}

1. Brabin B J, Hakimi M, Pelletier D. An Analysis of Anemia and Pregnancy-Related Maternal Mortality. $J$ Nutr. 2001;131(2):604-15.

2. Bondevik GT, Lie RT, Ulstein M, Kvale G. Maternal hematological status and risk of low birth weight and preterm delivery in Nepal. Acta Obstetricia et Gynecologica Scandinavica. 2001;80(5):402-8.

3. Kalaivani K. Prevalence \& consequences of anaemia in pregnancy. Indian J Med Res. 2009;130:627-33.

4. Jiang T, Christian P, Khatry SK, Wu L, West KPJ. Micronutrient Deficiencies in Early Pregnancy Are Common, Concurrent, and Vary by Season among Rural Nepali Pregnant Women. J Nutr. 2005;135(5):1106-12.

5. Dreyfuss ML, Stoltzfus RJ, Shrestha JB, Pradhan EK, LeClerq SC, Khatry SK et al. Hookworms, Malaria and Vitamin A Deficiency Contribute to Anemia and Iron Deficiency among Pregnant Women in the Plains of Nepal. J Nutr. 2009;130(10):2527-36. 
6. Siegel EH, Stoltzfus RJ, Khatry SK, LeClerq SC, Katz J, Tielsch JM. Epidemiology of anemia among 4- to 17-monthold children living in south central Nepal. European Journal of Clinical Nutrition. 2006;60:228-35.

7. Christian P, West KPJ, Khatry SK, Leclerq SC, Pradhan EK, Katz J et al. Effects of maternal micronutrient supplementation on fetal loss and infant mortality: a cluster-randomized trial in Nepal. Am J Clin Nutr. 2003;78(6):1194-1202.

8. Christian P, Stewart CP, LeClerq SC, Wu L, Katz J, West KPJ et al. Antenatal and Postnatal Iron Supplementation and Childhood Mortality in Rural Nepal: A Prospective Followup in a Randomized Controlled Community Trial. Am J Epidemiol. 2009;170(9):1127-36.

9. Allen LH. Anemia and iron deficiency: effects on pregnancy outcome. Am J Clin Nutr. 2000;71(5):1280-4.

10. Osrin D, Vaidya A, Shrestha Y, Baniya RB, Manandhar DS, Adhikari RK et al. Effects of antenatal multiple micronutrient supplementation on birthweight and gestational duration in Nepal: double-blind, randomized controlled trial. The Lancet. 2005;365(9463):955-62.

11. Levya A, Frasera D, Katzc M, Mazorc M, Sheiner E. Maternal anemia during pregnancy is an independent risk factor for low birth weight and preterm delivery. European Journal of Obstetrics \& Gynecology and Reproductive Biology. 2005;122(2):182-6.

12. Ren A, Wang J, Ye RW, Li S, Liu JM, Li Z. Low firsttrimester hemoglobin and low birth weight, preterm birth and small for gestational age newborns. International Journal of Gynecology \& Obstetrics. 2007;98(2):124-8.

13. Kidanto HL, Mogren I, Lindmark G, Massawe S, Nystrom L. Risks for preterm delivery and low birth weight are independently increased by severity of maternal anaemia. South African Medical Journal. 2009;99(2).

14. Sangvi TG, Harvey PWJ, Wainwright E. Maternal Iron-Folic Acid Supplementation Programs: Evidence of Impact and Implementation. Food and Nutrition Bulletin. 2010;31(2).
15. Imdad A, Bhutta ZA. Routine Iron/Folate Supplementation during Pregnancy: Effect on Maternal Anaemia and Birth Outcomes. Pediatric and Perinatal Epidemiology. 2012;26(1):168-77.

16. Ziaei S, Norrozi M, Faghihazadeh S, Jafarbegloo E. A randomized placebo-controlled trial to determine the effect of iron supplementation on pregnancy outcome in pregnant women with haemoglobin $>13.2 \mathrm{~g} / \mathrm{dl}$. British Journal of Obstetrics and Gynaecology. 2007;114(6):684-8.

17. Lawn JE, Yakoob MY, Haws RA, Soomro T, Darmstadt GL, Bhutta ZA. 3.2 million Stillbirths: epidemiology and overview of the evidence review. BMC Pregnancy and Childbirth. 2009;9.

18. Gardosi J, Madurasinghe V, Williams M, Malik, Francis AA. Maternal and fetal risk factors for stillbirth: population based study. BMJ. 2013;346.

19. Ellis M, Manandhar DS, Manandhar N, Wyatt J, Bolam AJ, Costello AM. Stillbirths and neonatal encephalopathy in Kathmandu, Nepal: an estimate of the contribution of birth asphyxia to perinatal mortality in a low $\square$ income urban population. Paediatric and Perinatal Epidemiology. 2000;14(1).

20. Gonzales GF, Steenland K, Tapia V. Maternal hemoglobin level and fetal outcome at low and high altitudes. American Journal of Physiology - Regulatory, Integrative and Comparative Physiology. 2009;297(5).

21. Stewart CP, Katz J, Khatry SK, LeClerq SC, Shrestha SR, West KP et al. Preterm delivery but not intrauterine growth retardation is associated with young maternal age among primipara in rural Nepal. Maternal \& Child Nutrition. 2007;3(3).

22. Lumbiganon P, Laopaiboon M, Gülmezoglu AM, Souza JP, Taneepanichskul S, Ruyan P et al. Method of delivery and pregnancy outcomes in Asia: the WHO global survey on maternal and perinatal health 2007-08. The Lancet. 2010;375(9713):490-9. 